microphytophagous species feeding on lower plant elements like fungal cushions, help in disseminating their spores in different soil layers (Haq, 1996). Effect of feeding by panphytophagous species appeared to be a combination of the above two as they assisted biodegradation by direct feeding on plant litter and indirectly by microbial activation. Luxton (1972) noted panphytophages as twice active as macrophytophages in processing dead organic material. Therefore, it can be concluded that combined activity of these three different feeding categories accelerated decomposition rate of organic litter.

Macrophytophagous oribatid mites were equipped with gnathal appendages which enabled effective trituration of large and hard food particles. Arrangement of gnathal appendages in microphytophagous species allowed only small particles to be consumed while pahphytophagous species possessed an intermedate organization of gnathal appendages.

\section{REFERENCES}

Pelletier, V.M.B. \& S.B. Hill (1978). Feeding habits and spore dispersal of oribatid mites in North American arctic. Revue D'Ecologie Et De Biologie Du Sd 15(4): 497-516.

Bhattacharya, S.K. (1962). Laboratory studies on the feeding and life cycles of soil inhabiting mites. Pedobiologia 1: 291-298.

Dinsdale, D. (1974). Feeding activity of a Phthiracarid mite (Arachnida: Acari). Journal of Zoology, London 174: 15-21.

Foster, A.S. (1960). Practical Plant Anatomy. $2^{\text {nd }}$ ed., Van Nostrand, 228pp. Haq, M.A. (1982). Feeding habits of ten species of oribatid mites (Acari: Oribatei) from Malabar, South India. Indian Journal of Acarology 6: 39-50. Haq, M.A. (1996). Nutritional diversity of oribatid mites in relation to soil fertility. Journal of the Karnataka University, Science Special Issue: 76-91.

Haq, M.A. \& N.R. Prabhoo. (1976). Observations on the feeding habits of mties from the soils of Kerala (Acarina: Cryptostigmata), Panphytophages. Entomon 1(2): 133-137.

Harding, D.J.L. \& R.A. Stuttard (1974). Microarthropods, pp.489-532. In: Biology of plant litter decomposition Vol.2. Dickinson, G.H. and C.J.P. Pough (eds.). Academic Press, London.

Kevan, D.K. Mc E. (1962). Soil Animals. London, Witherby Ltd. XV, 237pp. Kuhnelt, W. (1976). Soil Biology with special reference to the animal kingdom. Walker. N. Gaber, London, 397pp.

Luxton, M. (1972). Studies on the oribatid mites of Danish beech wood soil. Pedobiologia 12(5): 434-463.

Luxton, M. (1979). Food and energy processing by oribatid mites. Reveue D'Ecologie Et De Biologie Du Sd 16:103-111.

Ramani, N. \& M.A. Haq (2001). Feeding habits of the Indian oribtaid mite Hoplophthiracarus rimosus (Phthiracaridae) and Lohmannia n.sp. (Lohmanniidae) and their role in decomposition. Acarology proceedings of the $10^{\text {th }}$ International Congress: pp.262-265.

Sass, J.E. (1959). Botanical microtechnique, $3^{\text {rd }}$ Ed. Constable \& Co., London, 228 pp.

Schuster, R. (1956). Der Anteil der Oribatiden an den, Zergeitzungsr forgangen in Boden. Zool Morphologique Aeokologie. Tiere 45: 1-33.

Walwork, J.A. (1970). Ecology of soil animals. Mc. Graw Hill, London, New York, 283pp.

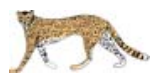

\title{
BALANTIDIUM AND TOXOCARA INFECTION IN LION (PANTHERA LEO) - A CASE REPORT
}

\section{Hase, P.B. ${ }^{1,2}$, S.U. Digraskar ${ }^{1}$, G.R. Gangane ${ }^{1}$, B.W. Narladakar ${ }^{1}$ and S.V. Razawi ${ }^{3}$}

${ }^{1}$ College of Veterinary and Animal Sciences, MAFSU, Parbhani, Maharashtra 431402, India

${ }^{3}$ Director, Siddharth Municipal Council Zoo Garden, Aurangabad, Maharashtra, India

Email: ${ }^{2}$ pankaj_hase@rediffmail.com

An 18-year old male lion "Amar" belonging to Siddharth Municipal Council Zoo Garden, Aurangabad (Maharashtra) was reported ill by the zoo authority. Clinical examination revealed dullness, depressed appetite, lethargy, epiphora, and loose faeces since three days. On clinical evaluation, the lion showed normal body temperature $\left(102^{\circ} \mathrm{F}\right)$, tachycardia (heart rate $85 / \mathrm{min}$.) and mild dehydration. The lion was secured in a squeeze cage and faecal and urine samples were collected for laboratory examination; blood sample from the coccygeal vein.

The coprological examination indicated heavy infection of intestinal protozoa-Balantidium coli and Toxocara sp. and mild strongyles infestations. Urine analysis revealed turbid appearance, positive for reducing sugar and presence of very large number of lipid droplets - Lipuria (adiposuria) on microscopic examination (Sastry, 2001). Haemogram indicated significant neutrophilia and eosionophilia.

The lion was treated with an antiprotozoan drug Metronidazole (Inj. Metrogyl) @ 20mg/kg b.w., b.i.d., i/v, Fenbendazole (Tab. Fentas) (a) $40 \mathrm{mg} / \mathrm{kg}$ b.w., orally, Dextrose (20\%) and electrolyte rich infusion (Inj. Rintose) - 500ml i/v, an antibiotic Ampicillin - Cloxacillin (Inj. AC - Vet) 2 gm i/m, Inj. Soda-bi-carb (7.5\%) - 20ml i/v, Vit. B1, B6 \& B12 (Inj Tribivet) - 8ml i/m and Antihistamine (Inj. Anistamin) $8 \mathrm{ml}$ $\mathrm{i} / \mathrm{m}$. The therapeutic regimen was continued for three consecutive days. The lion recovered on the fifth day of therapy and resumed normal appetite and physical activity.

Presence of parasites in the faeces and considering the success of antiparasitic treatment it can be concluded that the lion was suffering with clinical parasitosis. Zoo animals, especially canids, felids and ursids do not develop immunity and may become reinfected for the ascarids as compared to wild carnivores (Abdel-Rasoul \& Fowler, 1980). Canines and felines are prone to nephro- and hepatopathy as compared to other animals (Fowler, 1993). Abnormal constituents in urine, particularly lipuria could be attributed to improper fat metabolism consequent to hepatopathy and nephropathy triggered by chronic parasitism. Balantidium with concurrent infection of Toxocara sp. resulted in the clinical illness.

\section{REFERENCES}

Abdel-Rasoul, K.S. \& M. Fowler (1980). An epidemiologic approach to the control of ascariasis in zoo carnivores. Proceedings of the international symposium on diseases of zoo animals, Arnheim, Netherlands, 273pp.

Belding, D.L. (1965). Textbook of Parasitiology: $3^{\text {rd }}$ Edition: Applenton-Century-Crofts, New York, 1374pp

Fowler, M.E. (1993). Zoo Ẽ Wild Animal Medicine Current Therapy3. W.B. Saunders Company Philadelphia, 360-380pp.

Sastry, G.A. \& P.R. Rao (2001). Veterinary Pathology, $7^{\text {th }}$ Edition. CBS publication \& Distributors, New Delhi.

Patel, P.V., A.I. Patel, R.H. Sabapara, R.K. Sahu \& R. Vyas (2002). Helminthic infection in wild canids in zoological gardens of Gujarat. Zoos' Print Journal 18(4): 1084. Ruprah, N.S. (1985). A Textbook of Clinical Protozoalogy. Oxonian Press Pvt. Ltd. New Delhi, 356-362pp.

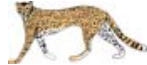

Manuscript 1600; (C) ZOO; Date of publication 21 April 2007 Received 22 July 2006; Revised received 08 February 2007; Finally accepted 16 March 2007 